\title{
Karakteristik Jelly drink Seledri dengan Variasi Konsentrasi Karagenan dan Agar
}

\author{
Nadlifatul Hasanah ${ }^{\mathrm{a}, 1, *}$, Isti Nurul Hidayah ${ }^{\mathrm{b}, 2}$, Iffah Muflihati ${ }^{\mathrm{b}, 3}$ \\ a Universitas PGRI Semarang, Jl. Sidodadi Timur, Dr. Cipto Semarang, 8316377 \\ ${ }^{\mathrm{b}}$ Universitas PGRI Semarang, Jl. Sidodadi Timur, Dr. Cipto Semarang, 8316377 \\ c Universitas PGRI Semarang, Jl. Sidodadi Timur, Dr. Cipto Semarang, 8316377) \\ ${ }^{1}$ nanda.nadlifah@gmail.com \\ *penulis korespondensi
}

\begin{abstract}
Jelly drink is the one of food product that can be as alternative drinks. One of the food that can be used is celery because most celery is only used as a mixture of soup and food ingredients. The purpose of this study was to determine the effect of carrageenan and agar ratio on syneresis, $p H$, total solids, and sensory of celery jelly drink. The study used a Completely Randomized Design with 4 treatments namely celery type A. Graveolens L. var sacalinum and A. Graveolens L. var sylvestre Alef and carrageenan: agar concentrations 80\%: 20\%, 60\%: 0.4\%. The results showed a mean syneresis of 2.33-6.39\%, average pH of 6.5-6.91, total dissolved solids ranged from 7.66 to $12{ }^{\circ}$ Brix, and the best treatment from sensory analysis was $60 \%$ concentration - $40 \%$ celery type A. Graveolens L. var sylvestre Alef.
\end{abstract}

Keywords: Agar, jelly drink, carrageenan, celery

\section{ABSTRAK}

Jelly drink merupakan salah satu alternative untuk memenuhi kebutuhan akan minuman yang praktis Salah satu bahan pangan yang dapat dimanfaatkan yaitu seledri karena sebagian besar seledri hanya digunakan sebagai campuran sup dan bahan makanan berkuah. Tujuan penelitian ini untuk mengetahui pengaruh perbandingan karagenan dan agar terhadap nilai sineresis, $\mathrm{pH}$, total padatan terlarut, dan uji organoleptik dari jelly drink seledri. Penelitian menggunakan Rancangan Acak Lengkap dengan 4 perlakuan yaitu jenis seledri A. Graveolens L. var sacalinum dan A. Graveolens L. var sylvestre Alef serta konsentrasi karagenan:agar yaitu 80\%:20\%, 60\%:0,4\%. Hasil penelitian menjukkan rerata sineresis yaitu 2,33-6,39\%, rerata $\mathrm{pH}$ berkisae 6,5-6,91, total padatan terlarut berkisar antara $7,66-12^{\circ}$ Brix, dan perlakuan terbaik dari uji organoleptic yaitu konsentrasi 60\%-40\% jenis seledri A. Graveolens L. var sylvestre Alef.

Kata Kunci: Agar, jelly drink, karagenan, seledri

\section{Pendahuluan}

Seledri (Apium graveolens L.) merupakan tanaman sayuran yang sudah lama dikenal di Indonesia. Tanaman seledri memiliki banyak manfaat. Daun dan tangkai daun seledri dapat digunakan sebagai campuran sup dan bahan makanan berkuah lainnya. Seledri juga dapat digunakan sebagai tanaman biofarmaka, yaitu untuk mengobati berbagai penyakit seperti demam, flu, gangguan pencernaan, limpa dan hati (Hendrika et al., 2017). Seledri (Apium graveolens $L$.) termasuk sayuran yang memiliki gizi yang cukup tinggi dan lengkap seperti protein, lemak, karbohidrat, kalsium, fosfor, zat besi, vitamin A, vitamin B1, vitamin C dan air. Senyawa kimia dari seledri yaitu zat glukosida, apiol, flavonoid, dan 
apiin. Zat-zat tersebut bermanfaat sebagai obat peluruh keringat, demam, darah tinggi, rematik dan sukar tidur (Jannah, 2016).

Karagenan termasuk senyawa kelompok polisakarida galaktosa hasil ekstraksi dari protein dan lignin rumput laut. Pemanfaatan karagenan sering digunakan dalam industri pangan karena memiliki karakteristik yang dapat berbentuk jelly, bersifat mengentalkan dan menstabilkan material utamanya. faktor yang mempengaruhi konsistensi antara lain: jenis karagenan, konsistensi, adanya ion-ion serta pelarut yang menghambat pembentukan hidrokoloid (Iglauer et al., 2011).

Perkembangan zaman membuat masyarakat lebih menyukai makanan dan minuman yang praktis sehingga mudah dikonsumsi. Jelly drink merupakan salah satu alternative untuk memenuhi kebutuhan akan minuman yang praktis tetapi memiliki gizi yang baik bagi tubuh. Jelly drink umumnya terbuat dari buah yang mengandung pektin (Novidahlia et al., 2019). Jelly drink tidak hanya sekedar minuman biasa, tetapi dapat dikonsumsi sebagai minuman penunda lapar. Tekstur yang diinginkan mudah hancur jika dikonsusmsi menggunakan bantuan sedotan, namun bentuk gelnya masih terasa di mulut (Agustin dan putri, 2014). Inovasi jelly drink seledri diharapkan dapat diterima oleh konsumen. Tujuan dari penelitian ini untuk mengetahui pengaruh perbandingan karagenan dan agar terhadap nilai sineresis, $\mathrm{pH}$, total padatan terlarut, dan uji organoleptik dari jelly drink seledri.

\section{Metode Penelitian}

\subsection{Bahan dan Alat}

Penelitian ini menggunakan bahan dasar daun seledri (Apium graveolens $\underline{\text { L.). Bahan }}$ tambahan yang digunakan adalah air, gula, garam, karagenan, dan agar. Bahan yang digunakan untuk analisis yaitu aquadest.

Peralatan yang digunakan yaitu baskom, blender, sendok, kain saring, kompor gas, panci, pengaduk kayu, timbangan digital, termometer, timbangan analitik, dan gelas ukur. Sedangkan peralatan yang digunakan untuk analisis refraktometer, $\mathrm{pH}$ meter, pipet dan gelas beaker.

\subsection{Rancangan Penelitian}

Rancangan percobaan yang digunakan adalah Rancangan Acak Lengkap (RAL) faktorial, dengan pola faktorial 2 x 2 dengan 3 kali pengulangan. Faktor perlakuannya adalah konsentrasi karagenan:agar dan jenis seledri. Faktor konsentrasi karagenan:agar terdiri dari 2 taraf (1=80\%:20\% dan 2=60\%:40\%), dan faktor jenis seledri terdiri dari dua taraf ( $\mathrm{A}=$ seledri kecil (A. Graveolens L. var. sacalinum) dan $\mathrm{B}=$ seledri besar (A. Graveolens L. var. sylvestre Alef)). Analisis yang dilakukan meliputi analisis sineresis, $\mathrm{pH}$, total padatan terlarut, dan uji organoleptik.

\subsection{Pelaksanaan Penelitian}

Prosedur pembuatan jelly drink seledri yaitu daun seledri disortasi dan dipisahkan dari batangnya kemudian dilakukan pencucian. Daun seledri diblanching selama 5 menit dengan suhu $70^{\circ} \mathrm{C}$. Penimbangan daun seledri dan penambahan air $1: 10$ lalu dihancurkan dengan blender. Kemudaian, dilakukan penyaringan untuk mendapatkan filtrat dari daun seledri. Penambahan karagenan : agar sesuai filtrat yang ditambahkan serta ditambah gula $10 \%$ dan garam secukupnya. Filtrat yang telah dicampur kemudian dipanaskan dengan suhu $75^{\circ} \mathrm{C}$ selama 5 menit. 


\subsection{Parameter Pengamatan}

\subsubsection{Sineresis}

Analisis sineresis dilakukan dengan memasukkan jelly drink ke dalam cup plastik dengan berat yang sama tiap perlakuan dan disimpan selama 24 jam, 48 jam, dan 72 jam dalam suhu refrigerator. Pengambilan sampel dilakukan dan kemudian mengambil air yang terpisah dari jelly drink kemudian ditimbang beratnya (Firdaus et al., 2018).

Rumus Perhitungan:

Tingkat sineresis $=\frac{\text { berat awal }(g)-\text { berat akhir }(g)}{\text { berat awal }(g)} \times 100 \%$

Keterangan:

Berat awal $=$ berat jelly drink dalam cup

Berat akhir = berat jelly drink dalam cup setelah dilakukan pemisahan air yang terlepas dari sistem gel.

\subsection{2 $\mathrm{pH}$}

Ujung elektroda pada $\mathrm{pH}$ meter dicelupkan sepanjang $4 \mathrm{~cm}$ ke dalam sampel jelly drink yang diuji. Nilai $\mathrm{pH}$ diperoleh dari hasil pembacaan angka yang tertera pada layar $\mathrm{pH}$ meter setelah kondisi spontan (Gani et al., 2014).

\subsubsection{Total padatan terlarut}

Pengujian total padatan terlarut dilakukan dengan menggunakan handrefractometer. Prisma refraktometer terlebih dahulu dibilas dengan aquades dan diseka dengan kain yang lembut. Sampel diteteskan ke atas prisma refraktometer dan diukur derajat Brix-nya (Bayu et al., 2017).

\subsubsection{Uji organoleptik}

Uji organoleptik terdiri dari uji deskriptif dan uji hedonik. Pengujian deskriptif dilakukan dengan 10 orang panelis terlatih. Saat pengujian deskriptif sampel ditempatkan pada cup plastik dan diberi kode nomor yang berbeda dengan jumlah 4 sampel. Sebelum pengujian deskriptif dilakukan, panelis dijelaskan bagaimana cara pengujian dan pengisisan kuisoner. Masing-masing sampel jelly drink seledri dengan konsentrasi karagenan, agar serta jenis seledri yang berbeda dilakukan pengujian berdasarkan indikator warna, aroma, rasa, kekenyalan, dan kemudahan disedot dengan menggunakan skala 1 sampai 5.

Uji hedonik dilakukan dengan 30 orang panelis tidak terlatih. Uji hedonik berdasarkan indikator warna, aroma, rasa, kekenyalan, kemudahan disedot dan overall. Skala penilaian uji hedonik dari skala 1 yaitu sangat tidak suka sampai skala 5 yaitu sangat suka.

\subsection{Analisis Data}

Data dianalisis dengan menggunakan Analisis Keragaman (ANOVA). Apabila terdapat perbedaan maka dilanjutkan dengan uji DMRT dengan taraf kepercayaan $95 \%$. Analisis data dengan menggunakan bantuan software computer SPSS 26.

\section{Hasil dan Pembahasan}

\subsection{Sineresis}


Sineresis merupakakan keluarnya air dari dalam gel sehingga menyebabkan gel mengkerut akibatnya gel nampak lebih kecil dan padat. Berdasarkan hasil analisis sineresis nilai yang dihasilkan lebih tinggi pada pengamatan 24 jam pada konsentrasi seledri besar (A. Graveolens L. var. sylvestre Alef) pada perbandingan karagenan : agar (80\%:20\%) dengan nilai 4,16, kemudian nilai terkecil pada konsentrasi seledri besar (A. Graveolens $L$. var. sylvestre Alef) perbandingan karagenan : agar (60\%:40\%) dengan nilai 3,05.

Pengamatan 48 jam nilai tertinggi pada konsentrasi seledri besar (A. Graveolens $L$. var. sylvestre Alef) pada perbandingan karagenan : agar (80\%:20\%) dengan nilai 5,55, kemudian nilai terkecil pada konsentrasi seledri besar (A. Graveolens L. var. sylvestre Alef) perbandingan karagenan : agar (60\%: 40\%) dengan nilai 3,33.

Pengamatan 72 jam nilai tertinggi pada konsentrasi seledri besar (A. Graveolens $L$. var. sylvestre Alef) pada perbandingan karagenan : agar (80\%:20\%) dengan nilai 6,39, kemudian nilai terkecil pada konsentrasi seledri besar (A. Graveolens L. var. sylvestre Alef) perbandingan karagenan : agar $(60 \%: 40 \%)$ dengan nilai 4.

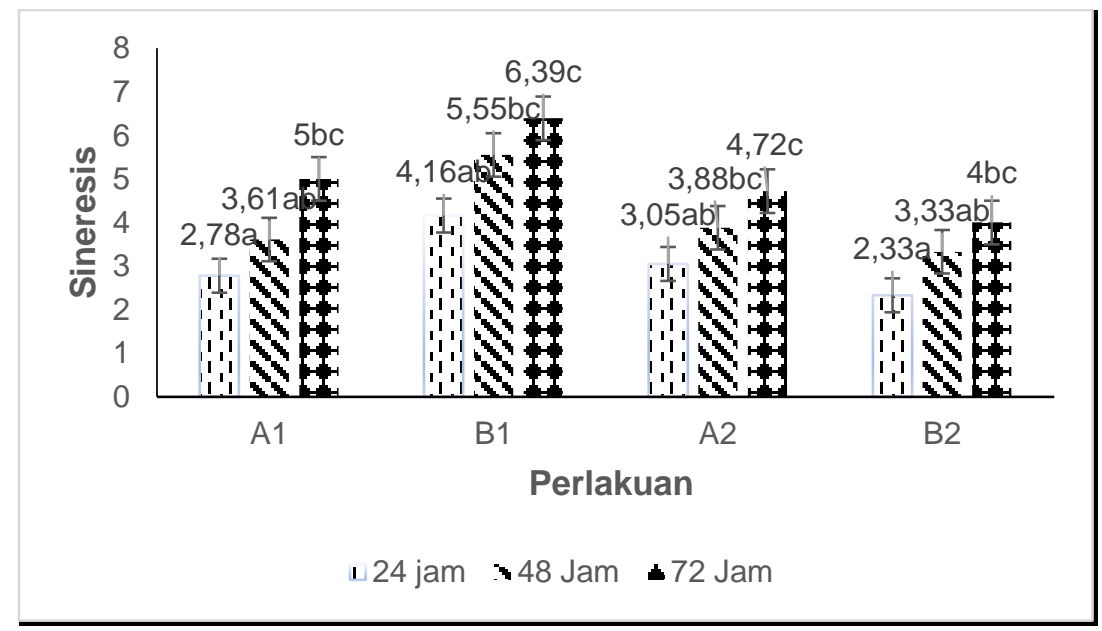

Gambar 1. Sineresis jelly drink

Berdasarkan pengamatan selama 24 jam, 48 jam, dan 72 jam dapat diketahui nilai sineresis tertinggi yaitu konsentrasi seledri besar (A. Graveolens L. var. sylvestre Alef) pada perbandingan karagenan : agar $(80 \%: 20 \%)$ dan nilai terkecil pada konsentrasi seledri besar (A. Graveolens L. var. sylvestre Alef) pada perbandingan karagenan : agar $(0,6 \%$ : $0,4 \%)$.

Menurut Agustin (2014) semakin tinggi konsentrasi karagenan yang ditambahkan maka nilai sineresis jelly drink semakin turun sedangkan menurut Muriana (2013) bahwa konsentrasi karagenan sebagai gelling agent yang ditambahkan terlalu kecil akan menyebabkan penyerapan air yang terlalu banyak sehingga gel yang terbentuk rapuh dan mengalami sineresis.

\section{$3.2 \mathrm{pH}$}

Berdasarkan hasil analisis diperoleh rerata $\mathrm{pH}$ pada jelly drink seledri anatar 6,56,91. Nilai rerata $\mathrm{pH}$ pada jelly drink seledri ditunjukkan pada Gambar 2. 


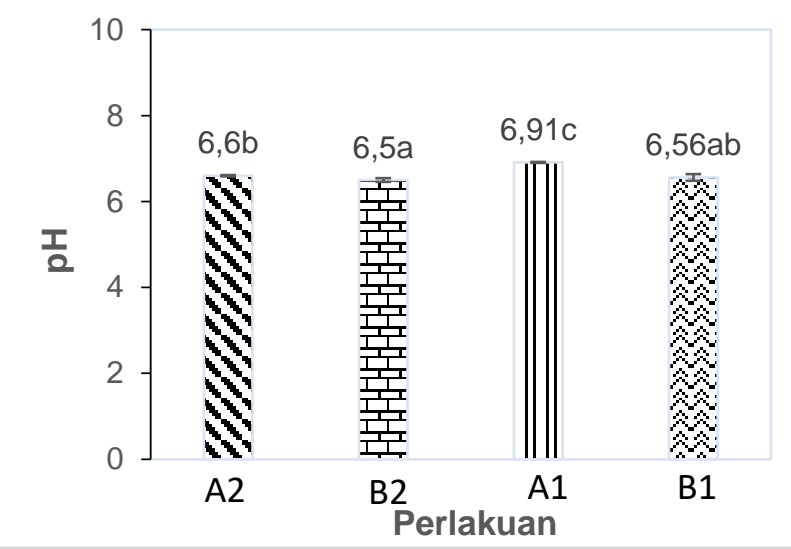

Gambar 2. pH jelly drink

Berdasarkan grafik pada gambar 2 terjadi peningkatan jenis seledri kecil $(A$. Graveolens L. var. sacalinum) dengan konsentrasi 60\%:40\% yaitu 6,6 dan 80\%:20\% dengan nilai 6,91 . Peningkatan nilai $\mathrm{pH}$ sejalan dengan penambahan air, dimana ion $\mathrm{H}+$ yang berasal dari asam-asam organik mengalami pengenceran, sehingga ion $\mathrm{H}+$ yang membentuk asam akan berkurang dan $\mathrm{pH}$ produk akan semakin meningkat (Yowandita, 2018). Karagenan dapat mempengaruhi peningkatan $\mathrm{pH}$. Hal ini disebabkan karagenan merupakan getah rumput laut yang diekstraksi dengan larutan alkali, sehingga memiliki $\mathrm{pH}$ basa. Gelling agent yang ditambahkan khususnya karagenan memiliki pH basa yaitu 9,510,5, sehingga dengan penambahan karagenan akan menetralkan asam-asam yang terdapat pada bahan dan $\mathrm{pH}$ akan semakin meningkat seiring dengan meningkatnya konsentrasi karagenan yang ditambahkan (Agustin dan Putri, 2014).

Perlakuan 60\%:40\% dan 80\%:20\% dengan jenis seledri besar (A. Graveolens $L$. var. sylvestre Alef) maupun kecil (A. Graveolens L. var. sacalinum) memiliki nilai $\mathrm{pH}$ terendah yaitu 6,5 dan 6,56. Menurut Yowandita (2018), suatu zat asam yang ditambahkan ke dalam air akan mengakibatkan bertambahnya ion hidrogen $(\mathrm{H}+)$ dalam air dan berkurangnya ion hidroksida $(\mathrm{OH}-)$, sehingga semakin bertambahnya ion hidrogen $(\mathrm{H}+)$ maka $\mathrm{pH}$ suatu zat akan semakin menurun. Jumlah asam yang ditambahkan dalam suatu larutan maka ion $\mathrm{H}+$ yang dilepaskan lebih besar sehingga menurunkan nilai $\mathrm{pH}$.

\subsection{Total Padatan Terlarut}

Berdasarkan Total Padatan Terlarut (TPT) menunjukkan bahwa seledri besar dengan konsentrasi (80\%:20\%) memiliki nilai tertinggi yaitu $12^{\circ}$ Brix, nilai kedua tertinggi pada perlakuan seledri kecil dengan konsentrasi (80\%:20\%) yaitu 9,46 ${ }^{\circ}$ Brix, nilai tertinggi ketiga yaitu seledri kecil dengan konsentrasi (60\%:40\%) yaitu $8^{\circ}$ Brix dan nilai terkecil pada perlakuan seledri besar dengan konsentrasi $(60 \% ; 40 \%)$ yaitu $7,66^{\circ}$ Brix. 


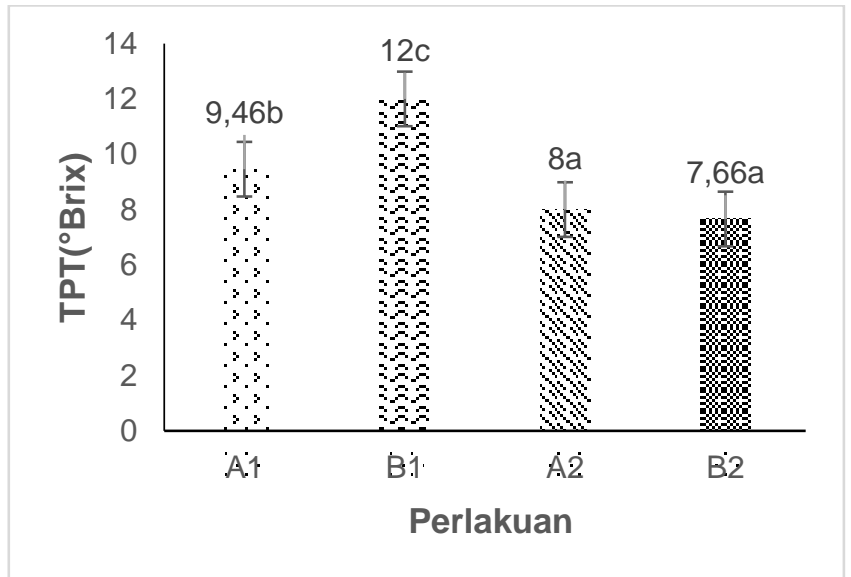

Gambar 3. Total padatan terlarut jelly drink

(Menurut Buckle (2009) Semakin tinggi proporsi gula yang ditambahkan maka total padatan terlarut dalam jelly drink akan semakin meningkat, karena gula memiliki daya larut yang tinggi sehingga kandungan padatan terlarut akan semakin tinggi seiring dengan semakin banyaknya proporsi penambahan gula yang ditambahkan. Menurut Rega (2011) yang meniliti mengenai pengaruh variasi konsentrasi ekstrak rosela dan karagenan (pengental) terhadap mutu minuman jelly drink menyatakan semakin tinggi konsentrasi ekstrak rosela dan karagenan yang ditambahkan maka semakin tinggi pula total padatan terlarut yang dihasilkan. Menurut Novidahlia (2019) konsentrasi karagenan dantepung porang yang kecil serta jumlah perlakuan yang diberikan sama sehingga nilai Total Padatan Terlarut Yang dihasilkan tidak mengalami perubahan yang signifikan.

\subsection{Uji Deskriptif}

Tabel 1. Uji Deskriptif

\begin{tabular}{|c|c|c|c|c|c|c|}
\hline \multirow{2}{*}{\multicolumn{2}{|c|}{ Perlakuan }} & \multirow{2}{*}{\multicolumn{5}{|c|}{ Nilai }} \\
\hline & & & & & & \\
\hline \multirow[t]{2}{*}{$80 \%: 20 \%$} & $\mathrm{~A}$ & $4.50 \pm 0.53^{c}$ & $1.70 \pm 0.95^{\mathrm{ab}}$ & $2.40 \pm 1.35^{a}$ & $3.50 \pm 1.27^{\mathrm{a}}$ & $2.20 \pm 1.69^{a}$ \\
\hline & B & $3.10 \pm 0.88^{\mathrm{ab}}$ & $2.70 \pm 1.70^{\mathrm{b}}$ & $2.40 \pm 1.58^{\mathrm{a}}$ & $3.50 \pm 1.27^{\mathrm{a}}$ & $1.70 \pm 1.64^{\mathrm{a}}$ \\
\hline \multirow[t]{2}{*}{$60 \%: 40 \%$} & A & $2.10 \pm 1.52^{\mathrm{a}}$ & $1.00 \pm 1.25^{\mathrm{a}}$ & $3.00 \pm 1.49^{a}$ & $2.70 \pm 1.70^{\mathrm{a}}$ & $4.00 \pm 1.15^{\mathrm{b}}$ \\
\hline & B & $3.70 \pm 1.25^{b c}$ & $2.40 \pm 1.71^{b}$ & $2.80 \pm 1.55^{\mathrm{a}}$ & $2.70 \pm 1.95^{\mathrm{a}}$ & $4.00 \pm 1.25^{b}$ \\
\hline
\end{tabular}

Keterangan : Nilai yang ditandai huruf yang sama menunjukkan tidak berbeda nyata ditaraf 5\% pada uji lanjut Duncan.

Skala (warna)

Skala (aroma)

Skala (rasa)

$=1:$ Putih, 5: Hijau

Skala (kekenyalan)

$=1$ : Lemah, 5: Kua

= 1: Tidak Manis, 5: Manis

$=1$ : Tidak Kenyal, 5: Kenyal

Skala (kemudahan disedot)

= 1: Sulit Disedot, 5: Mudah Disedot

Berdasarkan Tabel 1 uji deskriptif menunjukkan bahwa warna jelly drink perlakuan 80\%:20\% dan 60\%:40\% tidak berbeda nyata tetapi berbeda nyata dengan jenis daun seledri yang digunakan. Penambahan karagenan dan agar tidak berpengaruh terhadap warna jelly drink seledri karena karagenan dan agar tidak mengandung senyawa yang dapat membentuk warna ketika dicampurkan pada minuman. Waryoko (2007) menyatakan bentuk fisik karagenan menyerupai tepung dan berwarna putih, sehingga tidak berpengaruh terhadap warna bahan pangan. 
Aroma merupakan rangsangan yang ditimbulkan oleh bahan yang dicium, terutama yang dirasakan oleh indera pembau (Ashadi, 2014). Minuman jelly drink seledri yang paling dikhawatirkan adalah aroma seledri yang menyengat sehingga menimbulkan kesan yang tidak disukai oleh panelis. Aroma jelly drink perlakuan 80\%:20\% dan 60\%:40\% tidak berbeda nyata. Berdasarkan nilai rerata nilai respon panelis menunjukkan bahwa aroma yang baik yaitu konsentrasi 80\%:20\% dengan jenis daun seledri besar. Aroma dalam suatu system pangan tidak hanya ditentukan oleh satu komponen saja tetapi oleh beberapa komponen tertentu serta perbandingan jumlah komponen bahan (Widjaja et al., 2017).

Rasa merupakan faktor penerimaan konsumen terhadap makanan. Rasa suatu bahan pangan dipengaruhi oleh beberapa faktor senyawa kimia, suhu, konsistensi, dan interaksi dengan komponen rasa lain (Winarno, 2008). Table 2 menunjukkan bahwa rasa jelly drink seledri cenderung tidak berbeda nyata antara konsentrasi 80\%:20\% dan 60\%:40\% serta jenis seledri yang digunakan. Rasa jelly drink dipengaruhi oleh seledri dan gula yang ditambahkan. Penambahan gula bertujuan untuk memberikan cita rasa manis dan menutupi flavor dari seledri yang tidak disukai panelis. Rasa manis adalah rasa yang mempengaruhi cita rasa keseluruhan yang diperoleh dari penambahan gula dalam proses formulasinya (Wulandari et al., 2018).

Kekenyalan jelly drink seledri dari 2 konsentrasi dan 2 jenis seledri memberikan hasil yang tidak berbeda nyata. Hasil tertinggi kekenyalan pada konsentrasi 80\%:20\% yaitu 3,50. Kekenyalan merupakan daya perlawanan untuk mengalir dari system yang disebabkan oleh adanya gesekan, makin besar daya perlawanan maka akan semakin kental dan viskos. Karagenan akan mengikat air dalam jumlah besar, karena semakin banyak air yang terikat dan terperangkap sehingga larutan bersifat lebih kental (Wicaksono et al., 2015).

Kemudahan disedot memiliki perbedaan hasil yang berbeda nyata antara 2 konsentrasi karagenan dan agar. Hasil perlakuan meunjukkan bahwa konsentrasi karagenan dan agar 60\%:40\% mendapatkan hasil tertinggi yaitu 4,00 sehingga konsentrasi ini terbaik ketika produk disedot. Mutu kemudahan disedot dipengaruhi oleh konsentrasi dari karagenan dan agar, semakin tinggi konsentrasi karagenan dan agar maka akan semakin sulit jelly drink untuk disedot. Karagenan dan agar berperan sebagai gelling agent sehingga semakin tinggi konsentrasi yang ditambahkan maka teksturnya akan semakin kokoh dan sulit untuk disedot (Novidahlia et al., 2019).

\section{Hedonik}

\section{Tabel 2. Uji Hedonik}

\begin{tabular}{|c|c|c|c|c|c|c|c|}
\hline \multirow[t]{2}{*}{ Perlakuan } & & \multicolumn{6}{|c|}{ Nilai } \\
\hline & & Warna & Aroma & Rasa & Kekenyalan & $\begin{array}{l}\text { Kemudahan } \\
\text { disedot }\end{array}$ & Keseluruhan \\
\hline \multirow[t]{2}{*}{$80 \%: 20 \%$} & A & $3,46 \pm 0,89^{a}$ & $2,8 \pm 0,84^{\mathrm{a}}$ & $3,23 \pm 0,89^{a}$ & $3,7 \pm 0,79^{\mathrm{a}}$ & $2,36 \pm 0,85^{\mathrm{a}}$ & $3,06 \pm 0,82^{\mathrm{ab}}$ \\
\hline & B & $3,73 \pm 0,82^{\mathrm{a}}$ & $2,7 \pm 0,91 \mathrm{a}$ & $3 \pm 0,98^{\mathrm{a}}$ & $3,4 \pm 0,77^{\mathrm{a}}$ & $2,43 \pm 0,97^{\mathrm{a}}$ & $2,96 \pm 0,71^{\mathrm{a}}$ \\
\hline \multirow[t]{2}{*}{$60 \%: 40 \%$} & A & $3,33 \pm 0,84^{\mathrm{a}}$ & $3,3 \pm 0,91^{\mathrm{b}}$ & $3,3 \pm 0,87^{\mathrm{a}}$ & $3,56 \pm 0,89 a$ & $3,16 \pm 1,05^{\mathrm{b}}$ & $3,33 \pm 0,88^{a b}$ \\
\hline & B & $3,7 \pm 0,85 a$ & $2,96 \pm 0,88^{\mathrm{ab}}$ & $3,3 \pm 1,08^{\mathrm{a}}$ & $3,55 \pm 0,81^{\mathrm{a}}$ & $3,16 \pm 1,08^{b}$ & $3.50 \pm 0,80^{b}$ \\
\hline
\end{tabular}

Keterangan : Nilai yang ditandai huruf yang sama menunjukkan tidak berbeda nyata ditaraf $5 \%$ pada uji lanjut Duncan.

Skala : 1: Sangat Tidak Suka, 2: Tidak Suka, 3: Agak Suka, 4: Suka, 5: Sangat Suka

Berdasarkan Tabel 2. Uji Organoleptik "Hedonik" menunjukkan parameter warna produk jelly drink seledri perlakuan 80\%:20\% jenis seledri besar dan kecil tidak berbeda 
nyata dengan perlakuan 60\%:40\%. Parameter warna menunjukkan bahwa perlakuan 80\%:20\% seledri besar merupakan perlakuan yang terbaik dan disukai oleh panelis dengan nilai 3,73 .

Parameter aroma menunjukkan bahwa perlakuan 80\%:20\% tidak berbeda nyata dengan perlakuan 60\%:40\% jenis seledri besar sedangkan berbeda nyata dengan perlakuan 60\%:40\% jenis seledri kecil. Perlakuan 60\%:40\% seledri besar tidak berbeda nyata dengan jenis seledri besar perlakuan 60\%:40\%. Perlakuan 60\%:40\% jenis seledri kecil memiliki hasil yang tertinggi dan lebih disukai panelis dengan nilai 3,3.

Parameter rasa menunjukkan bahwa perlakuan 80\%:20\% seledri kecil dan besar tidak berbeda nyata dengan perlakuan 60\%:40\% seledri kecil dan besar. Parameter yang lebih disukai panelis yaitu perlakuan 60\%:40\% dari semua jenis seledri sebanyak 3,3.

Parameter kekenyalan menunjukkan tidak berbeda nyata antara perlakuan 80\%:20\% dan 60\%:40\% dari jenis seledri besar maupun seledri kecil. Kekenyalan dengan nilai tertinggi yaitu 3,7 pada perlakuan seledri kecil konsentrasi 80\%:20\% yang banyak disukai panelis.

Parameter kemudahan disedot dengan perlakuan 80\%:20\% menunjukkan tidak berbeda nyata antara jenis seledri kecil dan besar dan berbeda nyata pada perlakuan 60\%:40\% seledri kecil dan besar. Perlakuan 60\%:40\% tidak berbeda nyata antara seledri kecil dan besar. Perlakuan yang disuka oleh panelis yaitu konsentrasi 60\%:40\% dari semua jenis seledri yaitu 3,16.

Parameter keseluruhan perlakuan 80\%:20\% seledri kecil tidak berbeda nyata dengan perlakuan 60\%:40\% seledri kecil. Perlakuan 80\%:20\% berbeda nyata dengan perlakuan 0,6\%:0,2\% dengan jenis seledri besar. Panelis lebih menyukai perlakuan 60\%:40\% jenis seledri besar dengan nilai 3,50.

\section{Kesimpulan}

Berdasarkan analisis sineresis pada 24 jam, 48 jam, dan 72 jam menghasilkan nilai tertinggi pada seledri besar dengan konsentrasi (80\%:20\%). Analisis pH nilai tertinggi pada seledri kecil dengan konsentrasi (80\%:20\%) yang mendekati $\mathrm{pH}$ netral yaitu 6,91. Sedangkan analisis total padatan terlarut (TPT) menunjukkan bahwa seledri besar dengan konsentrasi (80\%:20\%) memiliki nilai tertinggi yaitu $12^{\circ}$ Brix. Uji Organoleptik yang paling disukai yaitu jelly drink seledri kecil dengan konsentrasi (60\%:40\%).

\section{Pustaka}

Agustin, F dan Putri, W.D.R. (2014). Pembuatan Jelly Drink Averrhoa Blimbi L. (Kajian Proporsi Belimbing Wuluh : Air dan Konsentrasi Karagenan). Jurnal Pangan dan Agroindustri, 2(3),1-9.

Ashadi, A., Susilo, B., Yulianingsih, R. (2014). Studi Komposisi Sari Jagung Manis dan Karagenan Pada Kualitas Jeli Jagung Manis. Jurnal Biopress Komoditas Tropis, 2(2), 161-169.

Bayu, M.K., Rizqiati, H., Nurwantoro. (2017). Analisis Total Padatan Terlarut, Keasaman, Kadar lemak, dan Tingkat Viskositas pada Kefir Optima dengan Lama Fermetasi yang Berbeda. Jurnal Teknologi Pangan, 1(1), 33-38. 
Buckle, K.A., R.A. Edward., G,H, Flet., and M, Wotton. (2009). Ilmu Pangan Edisi Ke Dua Belas. Terjemahan H. Purnomo dan Adiono. Jakarta: UI Press.

Firdaus, A.N., Kunarto., B. Sani, E.Y. (2018). Karakteristik Fisik dan Organoleptik Jelly Drink Berbasis Sari Jahe Emprit (Zingiber Officinale Rosc) dan Karagenan. Teknologi Hasil Pertanian. Universitas Semarang.

Gani, Y.F., Suseno, T.I.P. Surjoseputro, S. (2014). Perbedaan Konsentrasi Karagenan Terhadap Sifat Fisikokimia dan Organoleptik Jelly Drink Rosela-Sirsak. Jurnal Teknologi Pangan dan Gizi, 13(2), 87-93.

Hendrika, G. Rahayu., dan A. Mulyaningsih, Y. (2017). Pertumbuhan Tanaman Seledri (Apium graveolens L.) Pada Berbagai Komposisi Pupuk Organik dan Sintetik. Jurnal Agronida, 3(1), 1-9.

Iglauer, Stefan. (2011). Dilute Iota- And Kappa Carrageenan Solution With High Viscosities In High Salinity Brines. Journal of Petroleum science and Engineering, 75(3-4), 304-311.

Jannah, H. (2016). Pengaruh Paranet Pada Suhu dan Kelembaban Terhadap Pertumbuhan Tanaman Seledri (Apium graveolens L.). Jurnal Pendidikan Mandala, 1, 56-60.

Novidahlia, N., Rohmayanti, T.. Nurmilasari, Y. (2019). Karakteristik Fisikokimia Jelly Drink Daging Semangka, Albedo Semangka, dan Tomat Dengan Penambahan Karagenan dan Tepung Porang (Amorphophallus Muelleri Blume). Jurnal Agroindustry Halal, 5(1), 57-66.

Warkoyo. (2007). Studi Ekstraksi Karagenan dari Rumput Laut Eucheuma cottonii (Kajian Jenis Larutan Perendam dan Lama Perendaman). Jurnal, 14(1), 49-56.

Wicaksono, G.S., dan E. Zubaidah. (2015). Pengaruh Karagenan dan Lama Perebusan Daun Sirsak Terhadap Mutu dan Karakteristik Jelly Drink Daun Sirsak. Jurnal Pangan dan Agroindustri, 3(1), 281-291.

Widjaja, W.P., Sumartini., Rifani. (2017). Pengaruh Konsentrasi Jelly Powder Terhadap Karakteristik Minuman Jeli Ikan Lele (Clarias Sp.). Pasundan Food Technology Journal, 4(3). 198-207.

Winarno F.G. (2008). Kimia Pangan dan Gizi.Bogor. Bogor: M-Brio Press.

Wulandari, S., Kadekoh, I., Alam, N. (2018). Sifat Fisik Kimia dan Organoleptik Jelly Pada Berbagai Rasio Gula Pasir-Daging Buah Naga (Hylocereus polyrhizus Britt And Rose). e-Jurnal Agroteknis, 6(6), 789-797.

Yowandita, R. (2018). Pembuatan jelly Drink Nanas (Ananas comosus L) Kajian Tingkat Kematangan Buah Nanas dan Konsentrasi Penambahan Karagenan Terhadap Sifat Fisik, Kimia dan Organoleptik. Jurnal Pangan dan Agroindustri, 6(2). 63-73.

Muriana, E. (2013). Sifat Fisikokimia dan Organoleptik Jelly Drink Buah Naga Merah (Hylocereus polyrhizus) dengan Variasi Konsentrasi Karagenan. Skripsi. Fakultas Teknologi Pertanian UKWMS. Surabaya.

Rega, W. (2012). Pengaruh Variasi Konsentrasi Ekstrak Rosela dan Konsentrasi Bahan Pengental (Karagenan) Terhadap Mutu Minuman Jeli Rosela. Skripsi. Univ. Mulawarman, Samarinda.

Novidahlia Noli, Titi Rohmayanti, Yuni Nurmilasari. (2019). Karakteristik Fisikokimia Jelly Drink Daging Semangka, Albedo Semangka, dan Tomat dengan Penambahan 
Karagenan dan Tepung Porang (Amorphophallus muelleri Blume). Jurusan Teknologi Pangan dan Gizi, Fakultas Ilmu Pangan Halal Universitas Djuanda Bogor. 